\title{
Semiochemical-based alternatives to synthetic toxicant insecticides for pollen beetle management
}

\author{
Alice L. Mauchline ${ }^{1} \cdot$ Maxime R. Hervé $^{2} \cdot$ Samantha M. Cook $^{3}$
}

Received: 31 March 2017 / Accepted: 3 October 2017 / Published online: 19 October 2017

(C) The Author(s) 2017

\begin{abstract}
There is an urgent need to develop sustainable pest management systems to protect arable crops in order to replace the current over-reliance on synthetic insecticides. Semiochemicals are insect- or plant-derived chemicals that are used by organisms as information signals. Integrated pest management tools are currently in development that utilise semiochemicals to manipulate the behaviour of pest insects and their natural enemies to provide effective control of pests within the crop. These innovative tools usually require fewer inputs and can involve multiple elements, therefore reducing the likelihood of resistance developing compared with use of synthetic toxicants. We review here the life cycle of the pollen beetle Brassicogethes aeneus (previously known as Meligethes aeneus) which is a pest insect of oilseed rape (Brassica napus) and describe the current knowledge of any behaviour mediated by semiochemicals in this species. We discuss the behavioural processes where semiochemicalbased control approaches may be appropriate and consider how these approaches could be incorporated into an integrated pest management strategy for this important arable crop.
\end{abstract}

Keywords Meligethes - Brassicogethes aeneus. Integrated pest management $\cdot$ Oilseed rape $\cdot$ Brassica napus $\cdot$ Sustainable agriculture $\cdot$ Push-pull

Handling Editor: Heikki Hokkanen.

Alice L. Mauchline

a.1.mauchline@ reading.ac.uk

1 School of Agriculture, Policy and Development, University of Reading, Reading, Berkshire, UK

2 Université Rennes 1, UMR1349 IGEPP, 35000 Rennes, France

3 Biointeractions \& Crop Protection Department, Rothamsted Research, Harpenden, Hertfordshire, UK

\section{Introduction}

The pollen beetle Brassicogethes aeneus Fab. (synonym Meligethes aeneus) (Coleoptera: Nitidulidae) is a major pest of oilseed rape (OSR) (Brassica napus L.) crops (Williams 2010). Of the suite of pests that attack OSR, pollen beetles were found to have the largest negative impact on seed yield (Gagic et al. 2016). They can cause significant feeding damage to the developing flower buds which can result in blind stalks, thereby preventing the growth of pods, leading to large economic losses (Hansen 2004; Zlof 2008). Pyrethroid insecticides have been the main control option for pollen beetles for over 20 years. However, over-reliance on these and overuse of this single control strategy has led to B. aeneus populations developing resistance to this class of insecticide (e.g., Hansen 2003; Nauen et al. 2012; Zimmer et al. 2014). Although insecticides with alternative classes of active ingredients are now commercially available (see e.g., HGCA (2012)), alternative 'ecologically-based' approaches are needed to increase the sustainability of OSR cropping and to prevent further development of resistance (Cook and Denholm 2008).

Semiochemicals (a term derived from the Greek

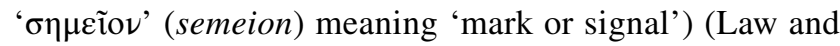
Regnier 1971) are chemicals that mediate interactions between organisms. These can be volatile or non-volatile signals that operate at long or short range (Eigenbrode et al. 2016) to modify the behaviour of the recipient. Plant- and insect-derived semiochemicals can be used for pest control to cause behavioural disruption of the pests themselves and/or their natural enemies (Cook et al. 2007b). These can provide sustainable control alternatives to the use of synthetic toxicant insecticides, however, they take a long time in development and still only make up a small fraction of the pest control market. There are several examples of 
semiochemical-based control methods that are currently in commercial usage for pest insect control; reviewed by Cook et al. (2007b) and Eigenbrode et al. (2016). They include insect attractants or stimulants, arrestants, repellents and deterrents. The only commercialised semiochemical-based method for pollen beetle control at the time of writing is a funnel trap baited with the 'most potent visual and chemical attractant stimuli for B. aeneus' for mass trapping in the early season. Use of semiochemicals in pest management of B. aeneus is therefore currently under-exploited. The most effective deployment of semiochemicals in pest management requires a full understanding of the biology and ecology of

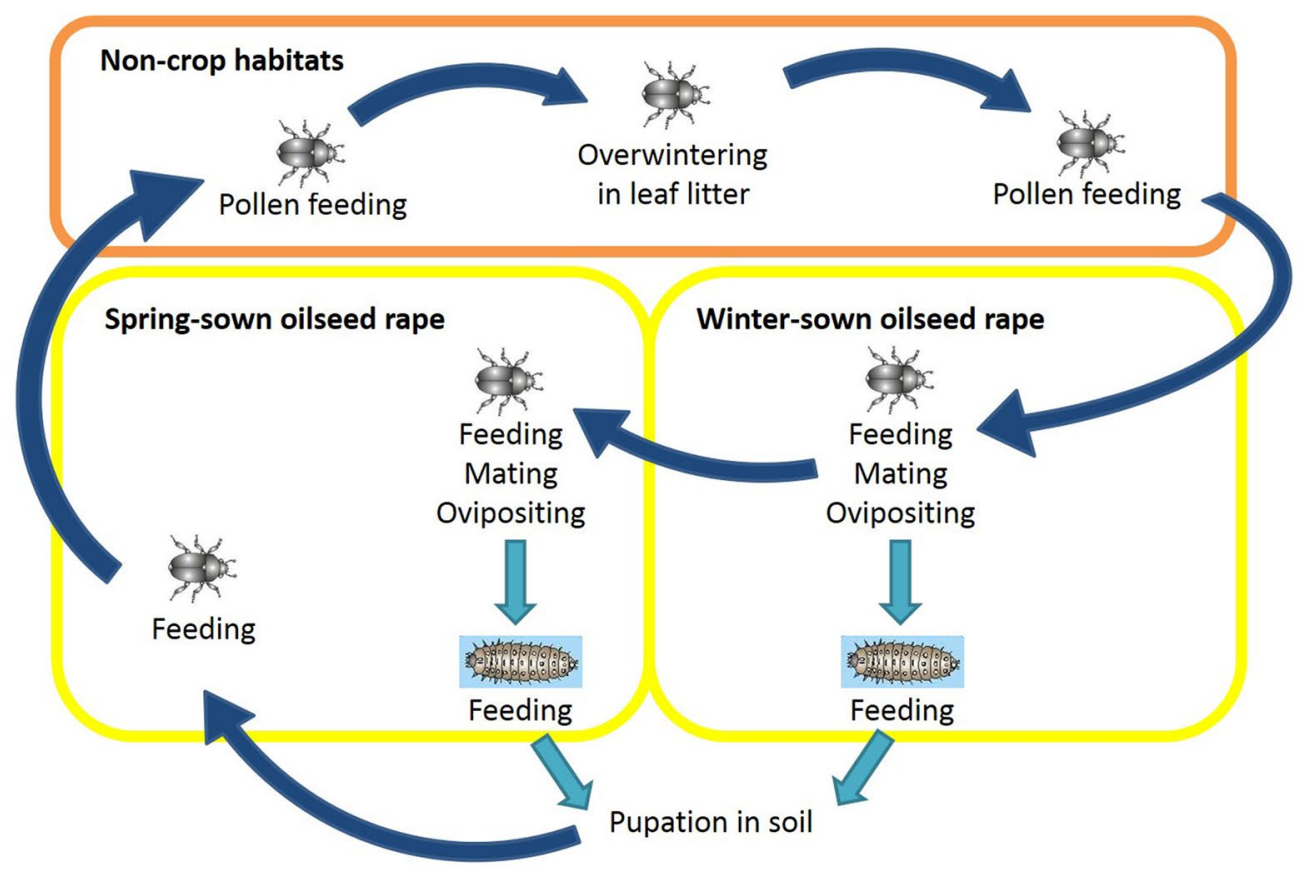

\begin{tabular}{|c|c|c|}
\hline $\begin{array}{l}\text { Behavioural process/life } \\
\text { stage }\end{array}$ & $\begin{array}{l}\text { Semiochemical cues in pollen beetle } \\
\text { behaviour }\end{array}$ & Potential control options \\
\hline $\begin{array}{l}\text { Emergence from } \\
\text { overwintering sites }\end{array}$ & Unknown & Mass trapping e.g. lure and kill \\
\hline $\begin{array}{l}\text { Food host-plant location } \\
\text { (generalist feeding) }\end{array}$ & $\begin{array}{l}\text { Long range cues; general plant } \\
\text { volatiles }\end{array}$ & $\begin{array}{l}\text { Attractants as lures for monitoring } \\
\text { traps and mass traps, } \\
\text { trap cropping, }\end{array}$ \\
\hline $\begin{array}{l}\text { Food host-plant acceptance } \\
\text { (generalist feeding) }\end{array}$ & $\begin{array}{l}\text { Short range cues; e.g. non-volatile } \\
\text { plant chemicals, phagostimulants }\end{array}$ & $\begin{array}{l}\text { Antifeedants, repellents, resistant } \\
\text { cultivars }\end{array}$ \\
\hline $\begin{array}{l}\text { Ovipositional host-plant } \\
\text { location (specialist on } \\
\text { brassicas) }\end{array}$ & $\begin{array}{l}\text { Long range cues; Specific plant } \\
\text { volatiles, non-host plant volatiles }\end{array}$ & $\begin{array}{l}\text { Trap cropping, repellents/ } \\
\text { deterrents, less attractive cultivars, } \\
\text { induced plant defence mechanisms }\end{array}$ \\
\hline $\begin{array}{l}\text { Ovipositional host-plant } \\
\text { acceptance (specialist on } \\
\text { brassicas) }\end{array}$ & $\begin{array}{l}\text { Short range cues; e.g. } \\
\text { Conspecific odour; epideictic and } \\
\text { ovipositional pheromones, plant } \\
\text { volatiles }\end{array}$ & $\begin{array}{l}\text { Oviposition deterrents, resistant } \\
\text { cultivars }\end{array}$ \\
\hline Mate location & Unknown & Mass trapping e.g. lure and kill \\
\hline Predation by natural enemies & $\begin{array}{l}\text { Use of plant host / prey odours by } \\
\text { parasitoids }\end{array}$ & $\begin{array}{l}\text { Enhanced biocontrol; induced plant } \\
\text { defence }\end{array}$ \\
\hline $\begin{array}{l}\text { Location of and movement to } \\
\text { overwintering sites }\end{array}$ & Unknown & Mass trapping e.g. lure and kill \\
\hline
\end{tabular}

Fig. 1 Life cycle of the pollen beetle showing behavioural processes that could be mediated by semiochemicals, along with a table of descriptions of the semiochemical cues and possible control opportunities (italics represent knowledge gaps) 
the pest insect (Agelopoulos et al. 1999; Cook et al. 2007b; Norin 2007; Heuskin et al. 2011) as well as an understanding of the scales at which the semiochemicals can be used to provide a holistic control strategy (Eigenbrode et al. 2016).

\section{Pollen beetle life cycle, semiochemical-mediated behaviour and opportunities for control}

This review covers the full life cycle of the pollen beetle (see Fig. 1) to provide an overview of the potential for semiochemical-mediated control in both oilseed rape crops and non-crop habitats. The control tools included in this review are either currently in development or are discussed as possible areas for research investment in the future. There are eight life stages or behavioural processes in the life cycle of the pollen beetle that are already known to be (or could be) mediated by semiochemical interactions and therefore offer the potential for control methods. These are (i) emergence from overwintering, (ii) food host-plant location, (iii) food host-plant acceptance, (iv) ovipositional host-plant location, (v) ovipositional host-plant acceptance, (vi) mate location, (vii) predation by natural enemies and (viii) location of and movement to overwintering sites. The current knowledge of the behavioural ecology of the pollen beetle is reviewed here followed by a discussion of potential opportunities for semiochemical-based control methods which exploit or disrupt their natural behaviours.

\section{Emergence from overwintering}

Pollen beetles overwinter as adults under the soil surface, in vegetation or leaf litter (Rusch et al. 2012; Gloyna and Thieme 2013). They emerge in early spring when temperatures reach a critical threshold (Fritzsche 1955; Hokkanen 1993; Marczali and Nádasy 2006). As pollen beetles emerge from overwintering sites, the ambient temperatures are usually low and the beetles are unlikely to be able to fly long distances; their propensity to fly follows a sigmoidal temperature-response curve between 6 and $23{ }^{\circ} \mathrm{C}$ (Ferguson et al. 2015).

\section{Semiochemical control options}

It is unknown if semiochemicals are involved in the emergence of pollen beetles in spring, and it seems unlikely. However, there is the potential to trap out large numbers shortly following emergence from hibernation using any semiochemical-baited attractant lures involved in food or mate location processes which occur in spring (see following sections). Baited traps would need to be positioned close to their overwintering sites which could significantly reduce populations prior to immigration to crops. In order to develop such mass trapping methods (e.g., Foster and Harris 1997; El-Sayed et al. 2006; Witzgall et al. 2010) or 'lure and kill' strategies (El-Sayed et al. 2009; Witzgall et al. 2010), more understanding is required about the overwintering sites of pollen beetles and their post-emergence behavioural processes to enable accurate predictions on where the overwintering sites are likely to be (Rusch et al. 2012; Gloyna and Thieme 2013) so that traps can be positioned in areas of high abundance in early spring with the most appropriate attractant semiochemical lure.

\section{Food host-plant location (long range cues)}

Following emergence from hibernation, pollen beetles move to find food host-plants. This is the first behavioural process in the pollen beetle life cycle that is known to be strongly influenced by semiochemical cues (reviewed by Williams and Cook 2010). Overwintered adult pollen beetles are generalist feeders on pollen from many different plant families to obtain nutrients for energy (Roulston and Cane 2000) and ovary maturation (Williams and Free 1978; Ouvrard et al. 2016). Pollen beetles locate their food host-plants, which include Brassicas, using a variety of plant semiochemical and visual cues.

Plants have complex biosynthetic pathways that lead to the release of volatile organic compounds, some of which are specifically released following herbivore damage (Turlings and Tumlinson 1992), and insects have evolved to use these volatiles as semiochemical cues in food host-plant location (Dicke and Baldwin 2010). Plant volatiles are a combination of ubiquitous volatiles emitted by all green plants including green leaf volatiles, terpenes and aromatic floral compounds, but some plant species also release species/genus-specific compounds such as the isothiocyanates released by Brassicaceae (Bruce et al. 2005). The response of the pollen beetle to these Brassica-specific cues is reviewed in the later section on ovipositional host-plant location.

Pollen beetles have been found feeding on a wide variety of wild plants (Williams and Free 1978; Mauchline 2003; Ouvrard et al. 2016) and are known to respond positively to whole plant odours from several non-Brassicaceous species including dandelion (Taraxacum officinale L.) (Cook 2000), field bean (Vicia faba L.) (Cook 2000), rye (Secale cereale L.) (Ruther and Thiemann 1997), tomato (Solanum lycopersicum L.) (Ruther and Thiemann 1997) and yarrow (Achillea millefolium L.) (Ruther and Thiemann 1997). Some of the semiochemicals responsible for this attraction have been identified. Brassicogethes aeneus was found to be attracted to general floral compounds such as phenylacetaldehyde and indole in the laboratory (Cook et al. 2007c) and field (Smart and Blight 2000). Their ability to detect and respond to a large number of chemically diverse plant volatiles may be 
an adaptation related to its polyphagous nature at this early life stage (Smart and Blight 2000).

\section{Semiochemical control options}

Pollen beetles cause the most damage when they feed on oilseed rape crops at the green bud stage. A monitoring trap is available from Oecos made from a yellow sticky card baited with phenylacetaldehyde; a common floral volatile produced naturally by several plant species. This monitoring trap uses the semiochemical lure to allow easier and more accurate measurement of beetle populations at this critical green bed stage and to establish when spray thresholds have been breached in crops.

\section{Food host-plant acceptance (short range/contact cues)}

Studies have shown that the volatile profile used by pollen beetles in host-plant location becomes less important after colonisation of a plant as they no longer respond to the same volatiles (Mauchline et al. 2013). At this stage, other chemical stimuli (surface and/or inner tissue semiochemicals) gained from close inspection of the plant become more important. Indeed, Charpentier (1985) found differences between host-plant feeding preferences of pollen beetles and concluded that chemical stimuli were the most important. Hervé et al. (2014) studied these stimuli by comparing six OSR genotypes for pollen beetle feeding preference, and identified possible phagostimulant/deterrent compounds in the bud perianth (the tissue that has to be pierced to access the food source) and in anthers (the tissue containing the food source). It was shown that only the composition of the perianth correlated with feeding damage, suggesting that this tissue is determinant in host-plant acceptance (Hervé et al. 2014). Among ca. 60 sugars, amino acids or secondary metabolites quantified, only five were clearly correlated with feeding damage: sucrose, proline, serine (positively correlated) and two glycosylated flavonols (negatively correlated). The latter are likely not to be biologically relevant for host-plant acceptance by the pollen beetle (Fellenberg and Vogt 2015). However, serine and especially sucrose-a well-known highly stimulant sugar (Chapman 2003) - are good candidates for further behavioural studies. Noticeably, glucosinolates did not seem to exert any major influence on pollen beetle feeding preference (Hervé et al. 2014).

At the interspecific scale, some plants have an attractive volatile profile, such as candytuft (Iberis amara L.), but are rejected by pollen beetles at the plant surface (Bartelt et al. 2004), indicating that they produce one or several strong feeding deterrents for pollen beetles. Antifeedants are nonvolatile chemicals that prevent or interrupt feeding through contact chemoreception or post-gustatory effects and these could be exploited for control purposes as reviewed by Cook et al. (2007b).

\section{Semiochemical control options}

The influence of semiochemical cues in host-plant acceptance for feeding within the pollen beetle life cycle is less well understood compared with host-plant location, although the important role of non-volatile chemical cues is clear. Further behavioural studies are required to identify all the chemical signals involved. Once identified, there is potential to breed OSR lines that have lower levels of phagostimulants to reduce susceptibility or have altered chemical profiles to deter feeding. Alternatively, effective exogenous antifeedant treatments could be developed such as those based on neem (Azadirachta indica A. Juss) extracts that are known to be effective against other herbivorous insects (Smart et al. 1994; Martel et al. 2005).

\section{Ovipositional host-plant location (long range cues)}

\section{Finding host-plants}

Brassicogethes aeneus is a specialist on Brassicas for oviposition (Free and Williams 1978; Williams and Free 1978; Ekbom and Borg 1996); therefore adult beetles use volatiles from OSR plants as cues for locating oviposition sites (by females) and potentially for mate location (by males) resulting in different behaviours on the plant. It is known that the pollen beetle has the ability to locate sources of OSR odour over long distances using upwind anemotaxis (Evans and Allen-Williams 1994; Williams et al. 2007a; Skellern et al. 2017), therefore this section discusses the various control options in development that rely on behavioural disruption during long-range OSR location.

Oilseed rape contains over 30 different glucosinolates (Chen and Andreasson 2001); sulphur-containing compounds that are important in defence against generalist phytophagous insects which are catabolised by myrosinase enzymes when the plant suffers insect attack (Giamoustaris and Mithen 1995; Grubb and Abel 2006). Some of these breakdown products are then released as volatile isothiocyanates which are used as semiochemicals for host location by those insects specialising on Brassicaceae (Hopkins et al. 2009; Ahuja et al. 2010; Bruce 2014) including pollen beetles (Blight et al. 1995; Blight and Smart 1999; Smart and Blight 2000).

Pollen beetles are known to be attracted to both visual (colour) cues (Cook et al. 2013b) and olfactory stimuli associated with their brassicaceous oviposition host-plants (Free and Williams 1978; Blight and Smart 1999; Smart and Blight 2000; Williams and Cook 2010). In laboratory tests, pollen beetles have been found to be attracted to 
volatiles from OSR in the bud stage (Evans and AllenWilliams 1994; Cook et al. 2007c; Jönsson and Anderson 2007), at the flowering stage (Evans and Allen-Williams 1994; Cook et al. 2002, 2006b), to floral volatiles from the OSR flower or part of the flower (Charpentier 1985; Byers 1992; Cook et al. 2002), as well as to pollen odour (Cook et al. 2002). The chemical basis for this attraction has been tested in the laboratory using electrophysiological studies and the most active compounds include 2-phenylethyl-, 3-butenyl- and 4-pentenyl- isothiocyanate, phenlyacetaldehyde and indole (Cook et al. 2007c). Such attraction has also been demonstrated in the field using baited traps (Smart et al. 1993, 1995; Cook et al. 2013a).

It is important to understand the context in which the semiochemical is detected, as the behavioural response to an odour can be affected by its concentration (Mauchline et al. 2005; Piesik et al. 2013) and by visual cues (Jonsson et al. 2007). A field trapping experiment showed that the magnitude of the effect of an attractant lure on trap catches of pollen beetle was dependent on the nature of the visual cue (Blight and Smart 1999); baited yellow traps caught more beetles than white traps indicating that pollen beetles have wavelength-specific preferences (Döring et al. 2012). Conversely, red and blue petal colours have been shown to reduce attractiveness to OSR flowers by pollen beetles (Cook et al. 2013b) and a recent study has shown that it is feasible to genetically modify $B$. napus by introducing key gene(s) from other species to create a different petal colour (Fu et al. 2017). This approach could lead to lines of red-coloured OSR which could disrupt long-range visual cues for beetles in flight and could be backed up by the use of close-range semiochemical-mediated disruption approaches to provide a second stage of protection. A further consideration is that insect feeding and oviposition damage cause altered emissions of volatile compounds (herbivore-induced plant volatiles) from plants. Piesik et al. (2013) found that feeding by B. aeneus suppressed the release of the lilac aldehydes and veratrole volatiles by OSR; whereas oviposition damage induced the release of three other common floral volatiles.

\section{Avoiding non-host-plants}

Non-host-plants are those plant species not used by an insect for oviposition or feeding and are recognised and avoided using similar cues as described in the previous section on host finding (Bruce and Pickett 2011). Ruther and Thiemann (1997) studied the olfactory response of pollen beetles to volatiles from host and non-host-plants and concluded that there must be some specific compounds which enable the beetles to distinguish between their host-plants and other plants. They suggested that OSR emits several compounds, such as isothiocyanates, that were missing in the plants used in their study. However, Bruce et al. (2005) argue that the weight of evidence is that insects identify their host-plants through central processing of olfactory signals following detection of specific ratios of ubiquitous plant volatiles.

Plant-derived repellents applied to crop plants could play a powerful role in pest management (Isman 2006). The behavioural response of pollen beetles to the volatile profile of essential oils from non-host-plants during host location was studied by Mauchline et al. (2005, 2008, 2013). Lavandula angustifolia Mill. (lavender) had the greatest repellent effect (Mauchline et al. 2005) and within this complex blend of volatiles, linalool and linalyl acetate were identified as the active compounds (Mauchline et al. 2008). Lavender odour caused a significant reduction in the number of adult pollen beetles in field plots if applied before crop colonisation (Mauchline et al. 2013). However, lavender oil is expensive; therefore, other essential oils have been investigated for similar efficacies (Pavela 2011; Daniel 2014). The highest repellency values were obtained for Mentha arvensis L., Cymbopogon flexuosus (Steud.) Wats. and Litsea cubeba (Lour.) Pers. (Daniel 2014). The commercialisation and application of essential oil-based repellents is limited as the active constituents are very volatile (Pavela 2011) and there are also issues relating to the scarcity of the natural resource, standardisation and registration of the product (Isman 2000). Slow-release solutions and devices are required for field application (Heuskin et al. 2011) and there is currently work underway to formulate lavender essential oil into a slow-release solution for field application as a repellent to pollen beetles.

\section{Semiochemical control options}

All of this evidence suggests that manipulation of host/ non-host-plant odours can be exploited in IPM strategies to reduce pollen beetle damage in three main ways; decreasing the inherent attractiveness of OSR to pollen beetles, using trap/companion plants and using non-host-plant-derived repellents/deterrents-which can all act either alone or in combination.

(i) Host-plant location of OSR crops during spring leads to feeding and oviposition and these behaviours cause damage to developing OSR crops, therefore it is extremely important to develop ways to manipulate and control large populations of this pest at this stage. Screening for and or/breeding OSR cultivars with low levels of attractive host-plant volatiles is an extremely promising avenue for further research to combine with other components into an integrated pest management strategy. 
Manipulation of the volatile profile of crop plants to reduce attractiveness to pest insects can be achieved through conventional plant breeding or genetic modification, but would probably be most effective if integrated into a two-component system with a second control element (Hervé and Cortesero 2016). The glucosinolate defence system in OSR with their breakdown products and volatile profiles offers great prospects for manipulation to achieve increased pest control (Ahuja et al. 2010). Transgenic OSR has been produced with low myrosinase activity (Borgen et al. 2010) which consequently reduces the production of glucosinolate hydrolysis products (mainly isothiocyanates). Compared to wild-type, these low isothiocyanate releasing seedlings were more preferred in free-choice experiments by generalist aphid species but less preferred by specialist aphid species (Borgen et al. 2012). However, such manipulation of plant volatile emissions can result in physiological costs to the plant (Robert et al. 2013) and it is imperative that any modifications do not impair the plant's natural ability to defend itself against other generalist pests after herbivore attack (Hopkins et al. 2009). Further, genetically modified OSR is unlikely to be accepted in Europe in the near future but the technology is in development and is already accepted in USA/Canada canola.

The main oilseed rape crop can be made relatively less without the need for genetic manipulation. The OSR cultivar 'Starlight' was found to have relatively lower proportions of alkenyl glucosinolates (i.e., those that break down to produce the volatile isothiocyanates such as 2-phenylethyl 3-butenyl- and 4-pentenyl- isothiocyanate to which pollen beetles are most attracted) and higher proportions of indole glusosinolates than conventional cultivars such as 'Canyon' (E Bartlet \& G Kiddle, unpubl.). Consequently the volatile profile of 'Starlight' was significantly less preferred in olfactometer tests and less colonised in field tests than conventional varieties (Cook et al. 2006b).

(ii) Trap cropping is a strategy that utilises attractive semiochemicals, released by plant species or crop cultivars that are more attractive than the main crop, to deter pests from the main crop (Hokkanen 1991; Shelton and Badenes-Perez 2006). In laboratory and field tests, pollen beetles showed a preference for turnip rape (Brassica rapa L.) over OSR (B. napus) (Büchi 1990; Cook et al. 2004b; Čuljak et al. 2016). The mechanism of action was investigated and found to be semiochemically mediated, at least in part, due to higher release rates of phenylacetaldehyde and indole in turnip rape, particularly in the bud stage, compared to OSR (Cook et al. 2007c). In addition, other close relatives of oilseed rape such Brassica nigra L. (Veromann et al. 2012), B. juncea (L.) Czern. and Sinapis alba L. (Kaasik et al. 2014) have also been shown to be more attractive to $B$. aeneus than $B$. napus plants so could also function as trap crops, however, the mechanism for this increased attraction is currently unknown.

(iii) Further research into non-host-plant semiochemistry has the potential to develop repellents and deterrents for use IPM strategies for the pollen beetle. However, effective slow-release formulations for field applications are required along with a more detailed understanding of the chemistry in order to develop this strategy. Also, timing is critical. Non-host-plant odour can be used effectively to repel pollen beetles from OSR, however, only if applied before crop infestation, i.e., during immigration flights (Mauchline et al. 2013). Understanding and predicting the triggers for these immigration flights (Mauchline et al. 2017) is crucial to the effective deployment of this element of the pest control strategy and the use of Decision Support Systems could help to optimise timing of such applications (Johnen et al. 2010; Johnen and von Richthofen 2013; Ferguson et al. 2016).

\section{Ovipositional host-plant acceptance (short range cues)}

When selecting ovipositional host-plants, pollen beetles have been shown to remain longer on suitable host-plants after landing, whereas they only stay for a short time on less preferred plants such as Sinapis alba (Borg and Ekbom 1996; Ekbom and Borg 1996). In their first description of the stereotypical oviposition behaviour of pollen beetles, Borg and Ekbom (1996) concluded that important cues for oviposition are located both on the bud surface and inside the bud. Hervé et al. (2015) went further in the description of this behaviour and of the sensory apparatus born by females' ovipositor, showing that both chemical and physical cues are likely to be used on the bud surface, whereas only physical cues are used inside the bud. These inner cues are probably related to anther shape, size or just presence. Indeed, it was shown in the field that adult females were more abundant on male-fertile (with anthers) OSR plants than on malesterile plants (with shrivelled anthers containing no pollen) during flowering of a varietal association hybrid crop, and a greater proportion of male-fertile than male-sterile buds were accepted for oviposition (Cook et al. 2004a).

Insect-insect semiochemical communication is also important during oviposition and host-plant acceptance behaviours (Anderson 2003). For example, pheromones such as the oviposition-deterring pheromone of another pest of OSR, the cabbage seed weevil (Ceutorhynchus assimilis Payk.) are deposited by females following oviposition to 
ensure that other conspecific females do not lay their eggs close-by (Ferguson and Williams 1989). Studies by Cook et al. (2006a) and Ruther and Thiemann (1997) found some evidence of a female epideictic (spacing) pheromone in pollen beetles in laboratory trials. In both studies, female beetles were repelled by the odours from a large group of females (200 individuals). This response was not shown in tests involving male beetles. These results suggest that females show epideictic behaviour in response to high densities of other females. It is suspected that several females commonly lay eggs in the same flower bud (Nilsson 1988); however, the presence of an epideictic pheromone could provide a mechanism to prevent intraspecific competition in the larvae. The behavioural response to the pheromone was found to be at least partially due to the odour of the females themselves, rather than due to the volatiles from femaledamaged plant material (Ruther and Thiemann 1997; Cook et al. 2006a). However, the effect of this putative epideictic pheromone was not detectable experimentally at the semifield or field scale (Cook et al. 2006a).

\section{Semiochemical control options}

The two semiochemical-based control options at this stage include (i) manipulation of plant cues that mediate ovipositional host-plant acceptance and (ii) pheromone-based oviposition deterrents.

(i) If the attractive bud surface chemical cues could be identified, there is scope to breed cultivars which have low amounts of these stimulant compounds. However, it is only known at this stage that glucosinolates are not major cues (Hervé et al. 2015). Alternatively, compounds which act as deterrents could be exogenously applied on the plants to reduce or prevent oviposition.

(ii) While there is some preliminary evidence of pheromone-mediated behaviour in female pollen beetles to prevent too many eggs being laid in one bud, this area needs further investigation to enable control tactics to be developed. Insect pheromones are volatile and so have short-lived effects. Chemical characterisation of the putative epideictic pheromone could lead to the synthesis of artificial compounds in a slow-release formulation that could be sprayed on the crop to act as a repellent.

\section{Mate location}

Attractant insect pheromones, such as sex and aggregation pheromones are species-specific semiochemical signals that have been identified and used successfully in many insect pest management programmes across the world (Baker and Heath 2004; Witzgall et al. 2010). There is currently no scientific evidence of any attractive pheromone in pollen beetles; however, such pheromone research is very well developed for other species, so is briefly reviewed here for completeness. Commonly used semiochemical-based techniques for insect pest control include: the release of synthetic sex pheromones to disrupt and prevent mating, e.g., in codling moths (Witzgall et al. 2008); the use of pheromone lures for monitoring, e.g., in the European corn borer (Laurent and Frérot 2007); and in mass-kill strategies, e.g., for the brinjal fruit and shoot borer (Cork et al. 2003). Aggregation pheromones attract both sexes and have been used in many applications for control and monitoring of insects, such as stored product pests (Trematerra 2012).

Male-produced aggregation pheromones have been identified in other species of Nitidulid beetles (Petroski et al. 1994; Bartelt et al. 2004), but there was no evidence for such a pheromone in pollen beetles in studies by Ruther and Thiemann (1997) and (Cook et al. 2006a).

Semiochemical control options: There is currently insufficient evidence to suggest that investigation into attractive pheromones would lead to the delivery of control tactics for pollen beetles.

\section{Predation by natural enemies}

Pollen beetles are predated by both specialist and generalist natural enemies. Generalist predators include Carabid and Staphylinid beetles as well as spiders. Additionally, several species of specialist parasitic wasp attack the larvae of pollen beetles, including Phradis interstitialis (Thomson), Phradis morionellus (Holmgren) and Tersilochus heterocerus (Thomson) which can have a significant impact on pollen beetle control (reviewed by Ulber et al. (2010) and Williams and Cook (2010)). There is evidence that semiochemicals mediate prey location (Williams et al. 2007b; Berger et al. 2015). Exploiting the current knowledge of the semiochemistry of host location by parasitoids could enhance biocontrol of pollen beetles within an IPM system as this has been already been achieved for aphid species in arable cropping systems (Du et al. 1998; Powell and Pickett 2003).

Olfactometer studies found that the three main species of pollen beetle parasitoid were all attracted to volatiles from OSR in the bud stage; however, there was an interesting finding of niche separation between the three competing species as they each displayed preferences for volatiles from insect infestations at different stages of OSR development that corresponded to their preferred host growth stage (Jonsson et al. 2005; Berger et al. 2015). After landing on the host-plant, T. heterocerus female parasitoids have also been shown to 
be attracted to volatiles from their pollen beetle host larvae (Straka et al. 2013; Berger et al. 2015). The volatiles released at a significantly higher rate from infested rape that were shown to be detected by $P$. morionellus antennae in electrophysiological studies were (Z)-3-hexenylacetate, $(Z)$ 3-hexenol, 3-butenyl isothiocyanate and $(E, E)$ - $\alpha$-farnesene (Jönsson and Anderson 2007).

\section{Semiochemical control options}

Pollen beetle parasitoids are known to use upwind anemotaxis for host-habitat location (Williams et al. 2007b); therefore, volatile semiochemical attractants could be used to attract these natural enemies as an in-field control measure.

\section{Location of and movement to overwintering sites}

New generation pollen beetles leave OSR crops as they cease flowering to feed on pollen of a wide range of later summerflowering plants in order to accumulate fat reserves; they then migrate to overwintering sites using daylength as the critical cue (Lipa and Hokkanen 1992). Pollen beetles overwinter in leaf litter within wooded areas or field margins and higher numbers of adults were found to be related to local landscape factors such relative altitude, litter thickness, soil moisture and proximity to the previous year's OSR fields (Rusch et al. 2012).

Gloyna and Thieme (2013) investigated overwintering distribution of pollen beetle in different biotypes and found that in suitable biotypes, distribution was highly heterogeneous, even at the small $\left(1 \mathrm{~m}^{2}\right)$ scale, with over 4000 found per $\mathrm{m}^{2}$ in some areas (pers. comm.), which suggests aggregation. This could be mediated by pheromones or could indicate very specific selection of suitable biotypes for overwintering. As described in the section on mate location, preliminary work did not find any evidence of an aggregation pheromone (Ruther and Thiemann 1997; Cook et al. 2006a). However, it is probable that the effect of such a pheromone would be life stage specific and that any potential aggregation (or other) pheromone only produced upon arrival at a suitable overwintering site; further research is therefore required to collect and test volatiles from overwintering insects in the field.

\section{Semiochemical control options}

This is a research gap clearly worth revisiting. The identification of an aggregation pheromone or other semiochemical cue used in this process at this stage of the beetle's life cycle could open up opportunities for a trapping method which could significantly reduce the overwintering population.
Fig. 2 The push-pull strategy of integrated pest management showing semiochemical manipulation of pest insects and non-insecticidal control methods

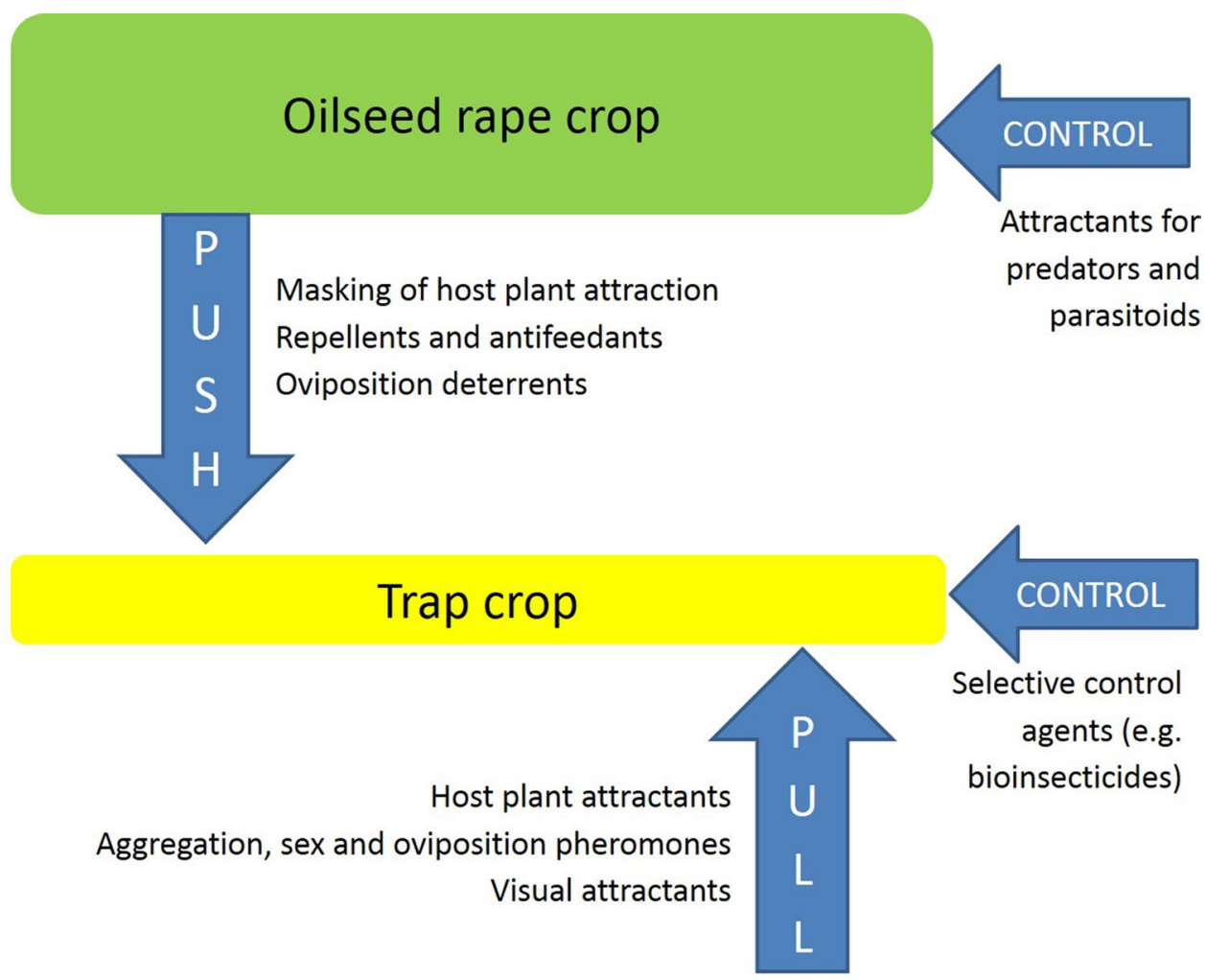




\section{Prospects for a semiochemical-based IPM strategy for pollen beetles}

This review has considered the important behavioural processes in the pollen beetle and the life stages at which they occur, where semiochemically mediated control could be developed as part of an IPM strategy. Individually, the alternative approaches reviewed here are likely to be less effective in terms of pest control compared to the use of an insecticide, however, integrating several of these semiochemical-based approaches into a holistic system could increase their overall efficacy while avoiding the harmful environmental impact of synthetic toxicant insecticides.

In general, most semiochemical-based control methods can be combined; however, it is pertinent to ensure they are not antagonistic to the aims of other IPM tools, e.g., biocontrol methods using natural enemies. The only study to date on pollen beetle control methods to check compatibility looked at the effect of lavender essential oil [a potential repellent (Mauchline et al. 2013)] on the behavioural responses of their two most common parasitoids. Both parasitoid species elicited electrophysiological responses to linalool and linalyl acetate (the compounds stimulating the repellent behaviour to lavender in pollen beetles), but gave no significant behavioural response at the concentrations effective against pollen beetles (Cook et al. 2007a). Therefore, there was no evidence to suggest that lavender-treated plants would negatively affect host location by parasitoids and hence both strategies could be deployed in tandem. However, further tests in field situations are necessary.

There are two holistic pest managment approaches currently in development that combine several elements of the control options reviewed here; namely the push-pull system and the potential for a smart, self-protecting crop.

\section{The push-pull system}

Push-pull is a formalised pest management strategy that combines attractant and repellent semiochemicals to manipulate pest and natural enemy populations (Miller and Strickler 1984; Pyke et al. 1987; Cook et al. 2007b) (Fig. 2). The pests are deterred from colonising or are 'pushed' out of the crop using, for example, repellent crop cultivars and repellent non-host-plant volatiles, plant-derived antifeedants and oviposition-deterring pheromones. The pests are simultaneously 'pulled' away from the crop into traps/trap crops using attractants such as host-plant volatiles or sex pheromones. A trap crop comprises plants which are designed to be even more attractive to the pest insect than the crop to be harvested (Hokkanen 1991; Shelton and Badenes-Perez 2006), i.e., exploiting host-plant preferences (Cook et al. 2006b). Once the pests have been concentrated on the trap crop, it can be treated if necessary with a selective biopesticide or synthetic insecticide, thus the area treated is reduced compared to conventional systems where the whole crop area is treated. Pests remaining in the main crop are controlled by natural enemies; their abundance potentially boosted using attractive 'pull' signals (Cook et al. 2007b). The components of the system need to be compatible with each other (Smart et al. 1997) and while individually they can be relatively ineffective compared to the use of broad-spectrum insecticides, together they can have an additive or synergistic effect (Campbell and Borden 2009). The combination of relatively weak control elements has the added advantage of not selecting strongly for resistance in the pest species (Pickett et al. 1997; Pickett and Khan 2016).

The push-pull system in development for pollen beetle control incorporates early season monitoring using semiochemical-baited traps (Cook et al. 2013a) followed by using an attractive border trap crop such as turnip rape (B. rapa) (Cook et al. 2004b, c; Čuljak et al. 2016) or B. nigra (Veromann et al. 2012, 2014) to provide the 'pull' element, as they are known to be a preferred host-plant for several OSR pests including the pollen beetle. Ideally, this should be a 'dead-end' trap crop (Shelton and Badenes-Perez 2006) such as Raphanus sativus (L.) Domin (Veromann et al. 2014). Biological control of the pollen beetles in the trap crop could be enhanced by attracting natural enemies using attractant lures based on host-plant volatiles (Jonsson et al. 2005; Jönsson and Anderson 2007) or volatiles from their host larvae (Straka et al. 2013; Berger et al. 2015), but this concept is still in the early research phase. As the push component, volatiles from lavender essential oil (Lavandula angustifolia) were found to be effective in deterring pollen beetles in laboratory bioassays (Mauchline et al. 2005, 2008) and in both semi-field and field trials (Mauchline et al. 2013). Analyses of data from a large-scale field plot experiment in OSR is underway to compare the efficacy of the combination of a repellent lavender spray along with a trap crop to reduce pollen beetle numbers in the main crop. This system is already at the field testing stage, however, slow-release formulations still need to be developed for release of the repellent volatiles; otherwise, this approach is close to practical use IPM system for oilseed rape growers.

\section{Smart, self-protecting crops}

A future avenue of research that is currently a bit further away from practical use is the development of oilseed rape plants that are 'self-protecting'. Attack from herbivores is known to induce natural plant defence systems (Pickett and Poppy 2001; Howe and Jander 2008); therefore, crop plants themselves could act as the source of manipulative semiochemicals, using inducing agents, or natural product plant activators, to 'switch on' plant defence prior to attack (Pickett et al. 2006). This alternative approach to genetic 
modification uses gene promoter systems that could create a self-protecting crop where primed sentinel crop plants use volatile signals to elicit faster defensive responses from the surrounding plants and natural enemies (Balmer et al. 2015; Conrath et al. 2015; Pickett and Khan 2016; Pickett 2016).

Taken together, these approaches may well deliver the sustainable pest control required to deliver food security without continued reliance on insecticides.

Acknowledgements This review was funded by the UK Defra Health \& Safety Executive (Chemicals Regulation Directorate) Project PS2141. Rothamsted Research receives strategic funding from the UK Biotechnology and Biological Sciences Research Council (BBSRC). SMC was part-funded by BBSRC Project BB/J004286/1.

Open Access This article is distributed under the terms of the Creative Commons Attribution 4.0 International License (http://creativecommons.org/licenses/by/4.0/), which permits unrestricted use, distribution, and reproduction in any medium, provided you give appropriate credit to the original author(s) and the source, provide a link to the Creative Commons license, and indicate if changes were made.

\section{References}

Agelopoulos N, Birkett MA, Hick AJ et al (1999) Exploiting semiochemicals in insect control. Pestic Sci 55:225-235. doi:10.1002/ (SICI)1096-9063(199903)55:3<225:AID-PS887>3.0.CO;2-7

Ahuja I, Rohloff J, Bones AM (2010) Defence mechanisms of Brassicaceae: implications for plant-insect interactions and potential for integrated pest management. A review. Agron Sustain Dev 30:311-348. doi:10.1051/agro/2009025

Anderson P (2003) Oviposition pheromones in herbivorous and carnivorous insects. In: Hilker M, Meiners T (eds) Chemoecology of insect eggs and egg deposition. Blackwell Publishing Ltd, Oxford, pp 235-263

Baker TC, Heath JJ (2004) Pheromones-function and use in insect control. In: Gilbert LI, Iatro K, Gill SS (eds) Molecular insect science. Elsevier, Amsterdam, pp 407-460

Balmer A, Pastor V, Gamir J et al (2015) The "prime-ome": towards a holistic approach to priming. Trends Plant Sci 20:443-452

Bartelt RJ, Kyhl JF, Ambourn AK et al (2004) Male-produced aggregation pheromone of Carpophilus sayi, a nitidulid vector of oak wilt disease, and pheromonal comparison with Carpophilus lugubris. Agric For Entomol 6:39-46. doi:10.1111/j.1461-9555.2004.00201.x

Berger J, Jönsson M, Hedlund K, Anderson P (2015) Niche separation of pollen beetle parasitoids. Front Ecol Evol 3:45. doi:10.3389/ fevo.2015.00045

Blight MM, Smart LE (1999) Influence of visual cues and isothiocyanate lures on capture of the pollen beetle, Meligethes aeneus in field traps. J Chem Ecol 25:1501-1516. doi:10.102 3/a:1020876513799

Blight MM, Pickett JA, Wadhams LJ, Woodcock CM (1995) Antennal perception of oilseed rape, Brassica napus (Brassicaceae), volatiles by the cabbage seed weevil Ceutorhynchus assimilis (Coleoptera, Curculionidae). J Chem Ecol 21:1649-1664. doi:10.1007/BF02033667

Borg A, Ekbom B (1996) Characteristics of oviposition behaviour of the pollen beetle, Meligethes aeneus on four different host plants. Entomol Exp Appl 81:277-284
Borgen BH, Thangstad OP, Ahuja I et al (2010) Removing the mustard oil bomb from seeds: transgenic ablation of myrosin cells in oilseed rape (Brassica napus) produces MINELESS seeds. J Exp Bot 61:1683-1697. doi:10.1093/jxb/erq039

Borgen BH, Ahuja I, Thangstad OP et al (2012) "Myrosin cells" are not a prerequisite for aphid feeding on oilseed rape (Brassica napus) but affect host plant preferences. Plant Biol 14:894-904. doi:10.1111/j.1438-8677.2012.00578.x

Bruce TJA (2014) Glucosinolates in oilseed rape: secondary metabolites that influence interactions with herbivores and their natural enemies. Ann Appl Biol 164:348-353. doi:10.1111/aab.12128

Bruce TJA, Pickett JA (2011) Perception of plant volatile blends by herbivorous insects-finding the right mix. Phytochemistry 72:1605-1611. doi:10.1016/j.phytochem.2011.04.011

Bruce TJA, Wadhams LJ, Woodcock CM (2005) Insect host location: a volatile situation. Trends Plant Sci 10:269-274. doi:10.1016/j. tplants.2005.04.003

Büchi R (1990) Investigations on the use of turnip rape as a trap plant to control oilseed rape pests. IOBC-WPRS Bull, 32-39

Byers JA (1992) Attraction of bark beetles, Tomicus piniperda, Hylurgops palliatus, and Trypodendron domesticum and other insects to short-chain alcohols and monoterpenes. J Chem Ecol 18:2385-2402. doi:10.1007/BF00984957

Campbell SA, Borden JH (2009) Additive and synergistic integration of multimodal cues of both hosts and non-hosts during host selection by woodboring insects. Oikos 118:553-563. doi:10.1111/j.1600-0706.2009.16761.x

Chapman RF (2003) Contact chemoreception in feeding by phytophagous insects. Annu Rev Entomol 48:455-484. doi:10.1146/ annurev.ento.48.091801.112629

Charpentier R (1985) Host plant selection by the pollen beetle Meligethes aeneus. Entomol Exp Appl 38:277-285. doi:10.1111/j.1570-7458.1985.tb03531.x

Chen S, Andreasson E (2001) Update on glucosinolate metabolism and transport. Plant Physiol Biochem 39:743-758

Conrath U, Beckers GJM, Langenbach CJG, Jaskiewicz MR (2015) Priming for enhanced defense. Annu Rev Phytopathol 53:97119. doi:10.1146/annurev-phyto-080614-120132

Cook S (2000) The use of pollen cues in resource location by a pollinator and a pest. $\mathrm{PhD}$ thesis. Nottingham University

Cook SM, Denholm I (2008) Ecological approaches to the control of pollen beetles in oilseed rape. EPPO Bull 38:110-113. doi:10.1111/j.1365-2338.2008.01192.x

Cook SM, Bartlet E, Murray DA, Williams IH (2002) The role of pollen odour in the attraction of pollen beetles to oilseed rape flowers. Entomol Exp Appl 104:43-50

Cook SM, Murray DA, Williams IH (2004a) Do pollen beetles need pollen? The effect of pollen on oviposition, survival, and development of a flower-feeding herbivore. Ecol Entomol 29:164-173. doi:10.1111/j.0307-6946.2004.00589.x

Cook SM, Watts NP, Hunter F, et al (2004b) Effects of a turnip rape trap crop on the spatial distribution of Meligethes aeneus and Ceutorhynchus assimilis in oilseed rape. IOBC-WPRS Bull, 199-206

Cook SM, Murray DA, Watts NP, Williams IH (2006a) Responses of pollen beetles (Meligethes aeneus) to conspecific odours. IOBCWPRS Bull 29(7):143-150

Cook SM, Smart LE, Martin JL et al (2006b) Exploitation of host plant preferences in pest management strategies for oilseed rape (Brassica napus). Entomol Exp Appl 119:221-229. doi:10.1111/j.1570-7458.2006.00419.x

Cook SM, Jönsson M, Skellern MP et al (2007a) Responses of Phradis parasitoids to volatiles of lavender, Lavendula angustifolia-a possible repellent for their host, Meligethes aeneus. Biocontrol 52:591-598. doi:10.1007/s10526-006-9057-x 
Cook SM, Khan ZR, Pickett JA (2007b) The use of push and pull strategies in integrated pest management. Annu Rev Entomol 52:375-400. doi:10.1146/annurev.ento.52.110405.091407

Cook SM, Rasmussen HB, Birkett MA et al (2007c) Behavioural and chemical ecology underlying the success of turnip rape (Brassica rapa) trap crops in protecting oilseed rape (Brassica napus) from the pollen beetle (Meligethes aeneus). Arthropod Plant Interact 1:57-67. doi:10.1007/s11829-007-9004-5

Cook SM, Döring TF, Andrew W, et al (2013a) Project Report No. 504 development of an integrated pest management strategy for control of pollen beetles in winter oilseed rape

Cook SM, Skellern MP, Döring TF, Pickett JA (2013b) Red oilseed rape? The potential for manipulation of petal colour in control strategies for the pollen beetle (Meligethes aeneus). Arthropod Plant Interact 7:249-258. doi:10.1007/s11829-013-9252-5

Cork A, Alam SN, Rouf FMA, Talekar NS (2003) Female sex pheromone of brinjal fruit and shoot borer, Leucinodes orbonalis (Lepidoptera: Pyralidae): trap optimization and application in IPM trials. Bull Entomol Res 93:107-113. doi:10.1079/ BER2002220

Čuljak TG, Pernar R, Juran I et al (2016) Impact of oilseed rape crop management systems on the spatial distribution of Brassicogethes aeneus (Fabricius 1775): implications for integrated pest management. Crop Prot 89:129-138. doi:10.1016/j. cropro.2016.07.017

Daniel C (2014) Olfactometer screening of repellent essential oils against the pollen beetle (Meligethes spp.). In: Integrated control in oilseed crops IOBC-WPRS Bulletin, pp 79-83

Dicke M, Baldwin IT (2010) The evolutionary context for herbivoreinduced plant volatiles: beyond the "cry for help". Trends Plant Sci 15:167-175. doi:10.1016/j.tplants.2009.12.002

Döring TF, Skellern M, Watts N, Cook SM (2012) Colour choice behaviour in the pollen beetle Meligethes aeneus (Coleoptera: Nitidulidae). Physiol entomol 37:360-378. doi:10.1111/j.1365-3032.2012.00850.x

Du Y, Poppy GUYM, Powell W et al (1998) Identification of semiochemicals released during aphid feeding that attract the parasitoid Aphidius ervi. J Chem Ecol 24:1355-1368

Eigenbrode SD, Birch ANE, Lindzey S et al (2016) A mechanistic framework to improve understanding and applications of pushpull systems in pest management. J Appl Ecol 53:202-212. doi:10.1111/1365-2664.12556

Ekbom B, Borg A (1996) Pollen beetle (Meligethes aeneus) oviposition and feeding preference on different host plant species. Entomol Exp Appl 78:291-299. doi:10.1111/j.1570-7458.1996.tb00793.x

El-Sayed AM, Suckling DM, Wearing CH, Byers JA (2006) Potential of mass trapping for long-term pest management and eradication of invasive species. J Econ Entomol 99:1550-1564

El-Sayed AM, Suckling DM, Byers JA et al (2009) Potential of "Lure and Kill" in long-term pest management and eradication of invasive species. J Econ Entomol 102:815-835. doi:10.1603/029.102.0301

Evans KA, Allen-Williams L (1994) Laboratory and field response of the pollen beetle, Meligethes aeneus, to the odour of oilseed rape. Physiol Entomol 19:285-290. doi:10.1111/j.1365-3032.1994. tb01054.X

Fellenberg C, Vogt T (2015) Evolutionarily conserved phenylpropanoid pattern on angiosperm pollen. Trends Plant Sci 20:212-218. doi:10.1016/j.tplants.2015.01.011

Ferguson AW, Williams IH (1989) Oviposition-deterring pheromone of the cabbage seed weevil (Ceutorhynchus assimilis Payk.). Asp Appl Biol 23:339-342

Ferguson AW, Nevard LM, Clark SJ, Cook SM (2015) Temperatureactivity relationships in Meligethes aeneus: implications for pest management. Pest Manag Sci 71:459-466. doi:10.1002/ps.3860
Ferguson AW, Skellern MP, Johnen A et al (2016) The potential of decision support systems to improve risk assessment for pollen beetle management in winter oilseed rape. Pest Manag Sci 72:609-617. doi:10.1002/ps.4069

Foster SP, Harris MO (1997) Behavioural manipulation methods for insect-pest management. Annu Rev Entomol 42:123-146. doi:10.1146/annurev.ento.42.1.123

Free JB, Williams IH (1978) The responses of the pollen beetle, Meligethes aeneus, and the seed weevil, Ceuthorhynchus assimilis, to oil-seed rape, Brassica napus, and other plants. J Appl Ecol 15:761-774

Fritzsche R (1955) Zur Morphologie von Meligethes aeneus Fabr., M. viridescens Fabr., M. coracinus Sturm und M. picipes Sturm. Beiträge zur Entomol 5:309-333

Fu W, Chen D, Pan Q, Li F, Zhao Z, Ge X, Li Z (2017) Production of red-flowered oilseed rape via the ectopic expression of Orychophragmus violaceus OvPAP2. Plant Biotechnol J. doi:10.1111/ pbi. 12777

Gagic V, Riggi LG, Ekbom B et al (2016) Interactive effects of pests increase seed yield. Ecol Evol 6:2149-2157. doi:10.1002/ ece 3.2003

Giamoustaris A, Mithen R (1995) The effect of modifying the glucosinolate content of leaves of oilseed rape (Brassica napus ssp. oleifera) on its interaction with specialist and generalist pests. Ann Appl Biol 126:347-363. doi:10.1111/j.1744-7348.1995. tb05371.xle

Gloyna K, Thieme T (2013) The hibernation of oil-seed rape pollen beetles (do beetles resistant to insecticides suffer a higher overwintering mortality?). IOBC-WPRS Bull 96:22

Grubb CD, Abel S (2006) Glucosinolate metabolism and its control. Trends Plant Sci 11:89-100. doi:10.1016/j.tplants.2005.12.006

Hansen LM (2003) Insecticide-resistant pollen beetles (Meligethes aeneus F.) found in Danish oilseed rape (Brassica napus L.) fields. Pest Manag Sci 59:1057-1059

Hansen LM (2004) Economic damage threshold model for pollen beetles (Meligethes aeneus F.) in spring oilseed rape (Brassica napus L.) crops. Crop Prot 23:43-46. doi:10.1016/ S0261-2194(03)00167-4

Hervé MR, Cortesero AM (2016) Potential for oilseed rape resistance in pollen beetle control. Arthropod Plant Interact 10:463-475. doi:10.1007/s11829-016-9438-8

Hervé MR, Delourme R, Gravot A et al (2014) Manipulating feeding stimulation to protect crops against insect pests? J Chem Ecol 40:1220-1231. doi:10.1007/s10886-014-0517-y

Hervé MR, Garcia N, Trabalon M et al (2015) Oviposition behavior of the pollen beetle (Meligethes aeneus): a functional study. J Insect Behav 28:107-119. doi:10.1007/s10905-015-9485-5

Heuskin S, Verheggen F, Haubruge E et al (2011) The use of semiochemical slow-release devices in integrated pest management strategies. Biotechnol Agron Soc 15:459-470

HGCA (2012) Oilseed rape guide

Hokkanen H (1991) Trap cropping in pest management. Annu Rev Entomol 36:119-138. doi:10.1146/annurev.ento.36.1.119

Hokkanen HMT (1993) Overwintering survival and spring emergence in Meligethes aeneus: effects of body weight, crowding, and soil treatment with Beauveria bassiana. Entomol Exp Appl 67:241246. doi:10.1111/j.1570-7458.1993.tb01674.x

Hopkins RJ, Van Dam NM, Van Loon JJA (2009) Role of glucosinolates in insect-plant relationships and multitrophic interactions. Annu Rev Entomol 54:57-83. doi:10.1146/annurev. ento.54.110807.090623

Howe GA, Jander G (2008) Plant immunity to insect herbivores. Annu Rev Plant Biol 59:41-66. doi:10.1146/annurev. arplant.59.032607.092825

Isman MB (2000) Plant essential oils for pest and disease management. Crop Prot 19:603-608 
Isman MB (2006) Botanical insecticides, deterrents, and repellents in modern agriculture and an increasingly regulated world. Annu Rev Entomol 51:45-66. doi:10.1146/annurev. ento.51.110104.151146

Johnen A, von Richthofen JS (2013) The decision-support system proPlant expert: a computer-based tool for integrated pest management in Europe. Bull IOBC/WPRS 96:99-105

Johnen A, Williams IH, Nilsson C et al (2010) The proPlant decision support system: phenological models for the major pests of oilseed rape and their key parasitoids in Europe. In: Williams IH (ed) Biocontrol-based integrated management of oilseed rape pests. Springer, Dordrecht, pp 381-403

Jönsson M, Anderson P (2007) Emission of oilseed rape volatiles after pollen beetle infestation; behavioural and electrophysiological responses in the parasitoid Phradis morionellus. Chemoecology 17:201-207. doi:10.1007/s00049-007-0379-7

Jonsson M, Lindkvist A, Anderson P (2005) Behavioural responses in three ichneumonid pollen beetle parasitoids to volatiles emitted from different phenological stages of oilseed rape. Entomol Exp Appl 115:363-369. doi:10.1111/j.1570-7458.2005.00271.x

Jonsson M, Rosdahl K, Anderson P (2007) Responses to olfactory and visual cues by over-wintered and summer generations of the pollen beetle, Meligethes aeneus. Short communication. Physiol Entomol. doi:10.1111/j.1365-3032.2007.00562.x

Kaasik R, Kovács G, Toome M et al (2014) The relative attractiveness of Brassica napus, B. rapa, B. juncea and Sinapis alba to pollen beetles. Biocontrol 59:19-28. doi:10.1007/ s10526-013-9540-0

Laurent P, Frérot B (2007) Monitoring of European corn borer with pheromone-baited traps: review of trapping system basics and remaining problems. J Econ Entomol 100:1797-1807. doi:10.1603/0022-0493(2007)100[1797:MOECBW]2.0.CO;2

Law JH, Regnier FE (1971) Pheromones. Annu Rev Biochem 40:533-548. doi:10.1146/annurev.bi.40.070171.002533

Lipa JJ, Hokkanen HMT (1992) Nosema meligethi I. \& R. (Microsporida) in populations of Meligethes spp. in Europe. Biocontrol. Sci Technol 2(2):119-125

Marczali Z, Nádasy M (2006) Wintering characteristic of the Meligethes species in Hungary. J Cent Eur Agric 7:283-288

Martel JW, Alford AR, Dickens JC (2005) Laboratory and greenhouse evaluation of a synthetic host volatile attractant for Colorado potato beetle, Leptinotarsa decemlineata (Say). Agric For Entomol 7:71-78. doi:10.1111/j.1461-9555.2005.00247.x

Mauchline A (2003) Behavioural and chemical ecology of Meligethes aeneus: effects of non-host plant volatiles. PhD thesis. The Open University

Mauchline AL, Osborne JL, Martin AP et al (2005) The effects of non-host plant essential oil volatiles on the behaviour of the pollen beetle Meligethes aeneus. Entomol Exp Appl 114:181188. doi:10.1111/j.1570-7458.2005.00237.x

Mauchline AL, Birkett MA, Woodcock CM et al (2008) Electrophysiological and behavioural responses of the pollen beetle, Meligethes aeneus, to volatiles from a non-host plant, lavender, Lavandula angustifolia (Lamiaceae). Arthropod Plant Interact 2:109-115. doi:10.1007/s11829-008-9038-3

Mauchline AL, Cook SM, Powell W, Osborne JL (2013) Effects of non-host plant odour on Meligethes aeneus during immigration to oilseed rape. Entomol Exp Appl 146:313-320. doi:10.1111/ eea. 12030

Mauchline AL, Cook SM, Powell W et al (2017) Migratory flight behaviour of the pollen beetle Meligethes aeneus. Pest Manag Sci. doi: $10.1002 / \mathrm{ps} .4550$

Miller JR, Strickler KL (1984) Finding and accepting host plants. In: Bell WJ, Cardé RT (eds) Chemical ecology of insects. Springer, New York, pp 127-157
Nauen R, Zimmer CT, Andrews M et al (2012) Target-site resistance to pyrethroids in European populations of pollen beetle, Meligethes aeneus F. Pestic Biochem Physiol 103:173-180. doi:10.1016/j.pestbp.2012.04.012

Nilsson C (1988) The pollen beetle (Meligethes aeneus $\mathrm{F}$.) in winter and spring rape at Alnarp 1976-1978. II. Oviposition. Växtskyddsnotiser 52:139-144

Norin T (2007) Semiochemicals for insect pest management. Pure Appl Chem 79:2129-2136. doi:10.1351/pac200779122129

Ouvrard P, Hicks DM, Mouland M et al (2016) Molecular taxonomic analysis of the plant associations of adult pollen beetles (Nitidulidae: Meligethinae), and the population structure of Brassicogethes aeneus. Genome 59:1101-1116. doi:10.1139/ gen-2016-0020

Pavela R (2011) Insecticidal and repellent activity of selected essential oils against of the pollen beetle, Meligethes aeneus (Fabricius) adults. Ind Crops Prod 34:888-892. doi:10.1016/j. indcrop.2011.02.014

Petroski RJ, Bartelt RJ, Weisleder D (1994) Biosynthesis of (2E,4E,6E)-5-ethyl-3-methyl-2,4,6-nonatriene: the aggregation pheromone of Carpophilus freemani (Coleoptera: Nitidulidae). Insect Biochem Mol Biol 24:69-78. doi:10.1016/0965-1748(94)90124-4

Pickett JA (2016) The essential need for GM crops. Nat Plants 2:16078. doi:10.1038/nplants.2016.78

Pickett JA, Khan ZR (2016) Plant volatile-mediated signalling and its application in agriculture: successes and challenges. New Phytol 212:856-870. doi:10.1111/nph.14274

Pickett JA, Poppy GM (2001) Switching on plant genes by external chemical signals. Trends Plant Sci 6:137-139. doi:10.1016/ S1360-1385(01)01899-4

Pickett JA, Wadhams LJ, Woodcock CM (1997) Developing sustainable pest control from chemical ecology. Agric Ecosyst Environ 64:149-156. doi:10.1016/S0167-8809(97)00033-9

Pickett JA, Bruce TJ, Chamberlain K et al (2006) Plant volatiles yielding new ways to exploit plant defence. In: Dicke M, Takken W (eds) Chemical ecology: from gene to ecosystem. Springer, Dordrecht, pp 161-173

Piesik D, Delaney KJ, Wenda-Piesik A et al (2013) Meligethes aeneus pollen-feeding suppresses, and oviposition induces, Brassica napus volatiles: beetle attraction/repellence to lilac aldehydes and veratrole. Chemoecology 23:241-250. doi:10.1007/s00049-013-0138-x

Powell W, Pickett JA (2003) Manipulation of parasitoids for aphid pest management: progress and prospects. Pest Manag Sci 59:149-155. doi:10.1002/ps.550

Pyke B, Rice M, Sabine B, Zalucki MP (1987) The push-pull strategy-behavioural control of Heliothis. Aust Cott Grow 9(1):7-9

Robert CAM, Erb M, Hiltpold I et al (2013) Genetically engineered maize plants reveal distinct costs and benefits of constitutive volatile emissions in the field. Plant Biotechnol J 11:628-639. doi:10.1111/pbi.12053

Roulston TH, Cane JH (2000) Pollen nutritional content and digestibility for animals. In: Dafni A, Hesse M, Pacini E (eds) Pollen and pollination. Springer, Vienna, pp 187-209

Rusch A, Valantin-Morison M, Roger-Estrade J, Sarthou JP (2012) Local and landscape determinants of pollen beetle abundance in overwintering habitats. Agric For Entomol 14:37-47. doi:10.1111/j.1461-9563.2011.00547.x

Ruther J, Thiemann K (1997) Response of the pollen beetle Meligethes aeneus to volatiles emitted by intact plants and conspecifics. Entomol Exp Appl 84:183-188. doi:10.102 3/A:1003040318376

Shelton A, Badenes-Perez FR (2006) Concepts and applications of trap cropping in pest management. Annu Rev Entomol 51:285308. doi:10.1146/annurev.ento.51.110104.150959 
Skellern MP, Welham SJ, Watts NP, Cook SM (2017) Agriculture, ecosystems and environment meteorological and landscape influences on pollen beetle immigration into oilseed rape crops. Ag Ecosyst Environ 241:150-159. doi:10.1016/j. agee.2017.03.008

Smart LE, Blight MM (2000) Response of the pollen beetle, Meligethes aeneus, to traps baited with volatiles from oilseed rape, Brassica napus. J Chem Ecol 26:1051-1064. doi:10.10 23/A:1005493100165

Smart LE, Blight MM, Hick AJ (1993) Development of a monitoring system for the cabbage seed weevil and the pollen beetle. IOBC/WPRS Bull 16:351-354

Smart LE, Blight MM, Pickett JA, Pye BJ (1994) Development of field strategies incorporating semiochemicals for the control of the pea and bean weevil, Sitona lineatus L. Crop Prot 13:127135. doi:10.1016/0261-2194(94)90163-5

Smart LE, Blight MM, Ryan J (1995) Response of pollen beetles, Meligethes spp., to volatiles from Brassica napus. In: Rapeseed today and tomorrow. Proceedings of the 9th international rapeseed congress, Cambridge, 4-7 July, pp 1040-1042

Smart LE, Pickett JA, Powell W (1997) "Push-pull” strategies for pest control. Grain Legum 15:14-15

Straka J, Anderson P, Hedlund K (2013) Host selection of Tersilochus heterocerus (Hymenoptera: Ichneumonidae), parasitoid of the pollen beetle Meligethes aeneus (Coleoptera: Nitidulidae). IOBC WPRS Bull 96:94

Trematerra $P$ (2012) Advances in the use of pheromones for storedproduct protection. J Pest Sci 85:285-299. doi:10.1007/ s10340-011-0407-9

Turlings TCJ, Tumlinson JH (1992) Systemic release of chemical signals by herbivore-injured corn. Proc Natl Acad Sci USA 89:8399-8402

Ulber B, Williams IH, Klukowski Z et al (2010) Parasitoids of oilseed rape pests in Europe: key species for conservation biocontrol. In: Williams IH (ed) Biocontrol-based integrated management of oilseed rape pests. Springer, Netherlands, Dordrecht, pp 45-76

Veromann E, Metspalu L, Williams IH et al (2012) Relative attractiveness of Brassica napus, Brassica nigra, Eruca sativa and Raphanus sativus for pollen beetle (Meligethes aeneus) and their potential for use in trap cropping. Arthropod Plant Interact 6:385-394. doi:10.1007/s11829-012-9191-6
Veromann E, Kaasik R, Kovács G et al (2014) Fatal attraction: search for a dead-end trap crop for the pollen beetle (Meligethes aeneus). Arthropod Plant Interact 8:373-381. doi:10.1007/ s11829-014-9325-0

Williams IH (2010) The major insect pests of oilseed rape in europe and their management: an overview. In: Williams IH (ed) Biocontrol-based integrated management of oilseed rape pests. Springer, Dordrecht, pp 1-43

Williams IH, Cook SM (2010) Crop location by oilseed rape pests and host location by their parasitoids. In: Williams IH (ed) Biocontrol-based integrated management of oilseed rape pests. Springer, Dordrecht, pp 215-244

Williams IH, Free JB (1978) The feeding and mating behaviour of pollen beetles (Meligethes aeneus Fab.) and seed weevils (Ceutorhynchus assimilis Payk.) on oil-seed rape (Brassica napus L.). J Agric Sci 91:453. doi:10.1017/S0021859600046554

Williams IH, Frearson D, Barari H, McCartney A (2007a) Migration to and dispersal from oilseed rape by the pollen beetle, Meligethes aeneus, in relation to wind direction. Agric For Entomol 9:279-286. doi:10.1111/j.1461-9563.2007.00343.x

Williams IH, Frearson DJT, Barari H, McCartney A (2007b) First field evidence that parasitoids use upwind anemotaxis for host-habitat location. Entomol Exp Appl 123:299-307. doi:10.1111/j.1570-7458.2007.00551.x

Witzgall P, Stelinski L, Gut L, Thomson D (2008) Codling moth management and chemical ecology. Annu Rev Entomol 53:503-522. doi:10.1146/annurev.ento.53.103106.093323

Witzgall P, Kirsch P, Cork A (2010) Sex pheromones and their impact on Pest Management. J Chem Ecol 36:80-100. doi:10.1007/s 10886-009-9737-y

Zimmer CT, Köhler H, Nauen R (2014) Baseline susceptibility and insecticide resistance monitoring in European populations of Meligethes aeneus and Ceutorhynchus assimilis collected in winter oilseed rape. Entomol Exp Appl 150:279-288. doi:10.1111/eea.12162

Zlof V (2008) Recommendations and conclusions of the Ad hoc EPPO Workshop on insecticide resistance of Meligethes spp. (pollen beetle) on oilseed rape. EPPO Bull 38:65-67. doi:10.1111/j.1365-2338.2008.01182.x 